\title{
Mengukur Konstitusionalitas Peninjauan Kembali (PK) Kedua dalam Perkara Perdata

\author{
\begin{tabular}{l|l} 
priyohandoko966@gmail.com & VIJ Sunan Ampel \\
& If. A. Yani 117 Sura6aya, Indonesia
\end{tabular}
} \\ Priyo Handoko
}

\begin{abstract}
The study aims to provide a constitutional analysis of judicial review (PK) in civil cases for more than once. The research-based is the decision of the Constitutional Court No. 108 / PUU-XIV / 2016 and No. 34 / PUU-XI / 2013 in which the two judgments provide a different classification between criminal and civil cases. The method used in this research is a normative juridical with a conceptual, legislation, and case approach. The results of the study assert that: first, the opportunity for judicial review (PK) more than once in a criminal case is an effort to uphold justice substantively by the Constitutional Court. Whereas the restriction of judicial review (PK) only once in civil cases is intended to guarantee legal certainty. Secondly, there is rational inconsistency in the arguments of the Constitutional Court which is indicated in Decision No. 108 / PUU-XIV / 2016 and No. 34 / PUU-XI / 2013. Both criminal and civil cases must seek to establish and maintain substantial justice, especially since there is a due process of law principle that requires that everyone can get the same opportunity before the law.
\end{abstract}

Keywords: Justice, Due Process of Law, and Constitutional Court

\begin{abstract}
Abstrak: Penelitian ini bertujuan untuk memberikan telaah secara konstitusional menakala peninjaun kembali (PK) dalam perkara perdata lebih dari satu kali. Penelitian ini berangkat dari putusan Mahkamah Konstitusi No. 108/PUU-XIV/2016 dan No. 34/PUU-XI/2013 yang mana dalam kedua putusan tersebut memberikan pengklasifikasian berbeda antara perkara pidana dan perdata. Metode penelitian yang digunakan oleh penulis ialah yuridis normatif, dengan pendekatan konseptual, pendekatan perundang-undangan dan pendekatan kasus. Hasil penelitian mengatakan bahwa: pertama, pemberian kesempatan upaya hukum peninjauan kembali (PK) lebih dari satu kali dalam perkara pidana oleh Mahkamah Konstitusi merupakan upaya untuk menegakkan keadilan
\end{abstract}


secara subtantif. Sedangkan pembatasan peninjauan kembali (PK) hanya satu kali dalam perkara perdata ialah dimaksudkan untuk menjamin kepastian hukum. Kedua, terdapat inkonsistensi dalam argumentasi Mahkamah Konstitusi yang ditunjukkan dalam putusan No. 108/PUUXIV/2016 dan No. 34/PUU-XI/2013. Sejatinya baik perkara pidana ataupun perdata harus mencari keadilan secara subtantif, terlebih ada asas hukum due process of law yang mengharuskan setiap orang dapat memperoleh kesempatan yang sama di depan hukum.

Kata kunci: keadilan, kepastian hukum, dan Mahkamah Konstitusi

\section{Pendahuluan}

Salah satu prinsip yang sangat esensial dalam suatu negara hukum ialah kedaulatan dalam negara. Sebagai core philosophy, kedaulatan negara telah termanifestasikan dalam sila-sila Pancasila, yang kemudian dirumuskan dalam sila ke-lima "keadilan social bagi seluruh rakyat Indonesia". ${ }^{1}$ Berdasarkan rumusan nilai tersebut seluruh elemen lembaga negara baik eksekutif, legislatif, maupun yudikatif dalam pengambilan setiap kebijakan harus memerhatikan keadilan kepada seluruh warga negaranya.

Amandemen UUD 1945 sebagai salah satu kesepakatan politis sejak tahun 1999-2002 2 telah berpegang teguh bahwa negara Indonesia ialah negara hukum. Resultante tersebut dapat kita baca melalui ketentuan Pasal 1 ayat (3) UUD 1945 yang mengatakan bahwa "Negara Indonesia adalah negara hukum". Konsekuensi logis dari adanya ketentuan tersebut, pemerintah harus bertanggungjawab serta memiliki kewajiban mutlak untuk melindungi dan mengayomi seluruh warga negaranya. Termasuk dalam hal ini ialah menempatkan setiap orang berkedudukan yang sama di depan hukum (equality before the law). Oleh sebab itu, konsep negara demokrasi Indonesia

1 Kaelan, Inkonsistensi dan Inkoherensi dalam Undang-undang Dasar Negara Republik Indonesia Tahun 1945 Hasil Amandemen (Kajian Filosofis dan Yuridis) (Yogyakarta: Paradigma, 2016), 107.

2 Muwahid, "Sistem Ketatanegaraan Indonesia Pasca Amandemen UUD 1945," Jurnal Al-Qa>nu>n 13, no. 2 (Desember 2010): 384. 
menempatkan norma atau hukum lebih tinggi dibandingkan dengan kekuasaan (the rule of law, not of man). Tentunya ini berwujud dengan bahwa hukum tidak boleh dibuat, ditetapkan, ditafsirkan, dan tegakkan oleh pemerintah berdasarkan kekuasaan belaka (maschstaat).

Sedangkan penegakan hukum (law inforcement) merupakan salah satu upaya untuk menjalakan normanorma dalam suatu peraturan perundang-undangan serta nilai-nilai yang terkandung di dalamnya. Oleh karenanya para penegak hukum harus benar-benar memahami spirit hukum yang mendasari pembuatan peraturan perundangundangan tersebut.

Gustav Readbruch pernah mengatakan bahwa dalam penegakan hukum setidaknya harus memenuhi tiga komponen utama, yaitu: keadilan, kebermanfaatan, dan kepastian hukum. ${ }^{3}$ Keadilan sangat erat kaitanya dengan kebanaran, tidak memihak (imparsial), dapat dipertanggungjawabkan serta menempatkan setiap orang dalam posisi yang sama di depan hukum (equality before the law). Sedangkan kebermanfaatan keberadaan hukum dapat menciptakan manfaat dan kebahagiaan kepada seluruh masyarakat. Dan kepastian hukum berkaitan dengan aspek kepastian hukum kepada masyarakat.

$$
\text { Namun dalam praktiknya, seringkali }
$$
pengimplementasian unsur-unsur tersebut tidak dapat dilaksanakan secara berimbang. Adakalanya hakim sebagai pemutus perkara mengesampingkan salah satu diantaranya. Kasus yang menarik terkait dengan hal tersebut ialah keberadaan Putusan Mahkamah Konstitusi No. 34/PUUXI/2013 tentang pengujian Pasal 268 ayat (3) UndangUndang Nomor 8 Tahun 1981 tentang hukum acara pidana. Mahkamah Konstitusi dalam pengujian UU tersebut memutusakan bahwa: "Peninjauan kembali atas suatu putusan hanya dapat dilakukan satu kali, bertentangan

3 Nafi' Mubarok, "Penemuan Hukum sebagai Pertimbangan Sosiologis Hakim Agama dalam Menerapkan Hukum," Jurnal Al-Qānūn 17, no. 2 (Desember 2014): 370 . 
dengan UUD 1945 dan tidak mempunyai kekuatan hukum mengikat".

Atas putusan Mahkamah Konstitusi tersebut, banyak dari kalangan masyarakat yang setuju, dan bahkan tidak sedikit pula yang menolak. Bagi mereka yang setuju beranggapan bahwa Peninjauan Kembali (PK) lebih satu kali merupakan upaya untuk melindungi hak-hak asasi masusia yang telah mendapatkan perlindungan dari konstitusi. ${ }^{4}$ Sedangkan bagi mereka yang menolak mendalilkan bahwa putusan MK yang memperbolehkan PK kedua dalam kasus pidana tersebut akan menghilangkan prinsip kepastian hukum, yang bisa menyebabkan keadilan tersandera hingga dapat merugikan pencari keadilan itu sendiri. ${ }^{5}$

Disisi lain Mahkamah Agung juga merespon putusan MK tersebut melalui Surat Edaran Mahkamah Agung (SEMA) No. 7 Tahun 2014 tentang pengajuan permohonan peninjauan kembali, yang substansinya telah bertentangan dengan putusan MK.

Namun seiring dengan berjalannya waktu, terdapat pengujian Pasal 66 ayat (1) UU No. 14 Tahun 1985 sebagaimana diubah dengan UU No. 5 Tahun 2004 tentang Mahkamah Agung. Pemohon mendalilkan bahwa seharusnya PK ke dua bukan hanya berlaku dalam perkara pidana saja, melainkan perkara yang lain layaknya perdata dan administrasi negara. Karena kesemuanya memiliki upaya hukum luar biasa layaknya peninjauan kembali. ${ }^{6}$

Namun berbeda dengan putusan sebelumnya (Putusan No. 34/PUU-XI/2013), Mahkamah Konstitusi melalui putusanya No. 108/PUU-XIV/2016 telah menolak keseluruhan permohonan pemohon dan menyatakan bahwa

4 Ani Triwati, "Upaya Hukum Peninjauan Kembali Dalam Perkara Pidana Pasca Putusan Mahkamah Konstitusi," Jurnal Dinamika Sosial Budaya 17, no. 2 (2015): 13.

5 Budi Suhariyanto, "Aspek Hukum Peninjauan Kembali Lebih dari Satu Kali dalam Perkara Pidana (Perspektif Penegakan Keadilan, Kepastian dan Kemanfaatan Hukum)," Jurnal Hukum dan Peradilan 4, no. 2 (2015): 337.

6 Pityani Meutia, "Pembatasan Peninjauan Kembali Perkara Perdata Kajian Putusan Mahkamah Konstitusi Nomor 108/PUU-XIV/2016," Jurnal Legislasi Indonesia 16, no. 2 (2019): 226. 
peninjauan kembali lebih dari satu kali hanya berlaku untuk perkara pidana. Upaya hukum luar biasa bertujuan menemukan keadilan dan kebenaran materiel tanpa dibatasi oleh limitasi waktu. Dengan adanya pembatasan peninjauan kembali hanya satu kali telah secara nyata membatasi pencarian keadilan. ${ }^{7}$

Atas dasar itulah, penelitian ini dilakukan dengan judul "Mengukur Konstitusionalitas Peninjauan Kembali (PK) ke-dua Dalam Perkara Perdata". Setidaknya ada beberapa rumusan masalah yang diajukan oleh penulis. Pertama, apa ratio decidendi Putusan Mahkamah Konstitusi No. 34/PUU-XI/2013 dan No. 108/PUU-XIV/2016 sebagai dasar pembedaan pemberian kesempatan PK Ke-2 antara kasus pidana dan perdata? Kedua, Sejauhmana perlindungan yang diberikan oleh konstitusi terhadap hak-hak warganegara dalam perkara pidana dan perdata? Ketiga, Bagaimana pandangan hukum Islam dalam memberikan kesempatan upaya hukum bagi seseorang yang telah dinyatakan bersalah?

\section{Metode Penelitian}

Penelian ini merupakan penilitian hukum normatif (normative legal research) yang manjadikan norma dan kaidah dasar, asas-asas hukum, peraturan perundangundangan, doktrin sebagai objeknya. ${ }^{8}$ Terdapat tiga pendekatan yang digunakan, yaitu:

1. Perundang-undangan (statute approach), yaitu dengan menggunakan ialah UU No. 3 Tahun 2009 sebagaimana perubahan kedua atas UU No. 18 Tahun 1985 tentang Mahkamah Agung, SEMA No. 10 Tahun 2009, dan SEMA No. 7 Tahun 2014.

2. Pendekatan konseptual (conceptual approach), yaitu berkaitan dengan teori dan konsep peninjauan kembali.

7 Triwati, "Upaya Hukum Peninjauan Kembali Dalam Perkara Pidana Pasca Putusan Mahkamah Konstitusi," 13.

8 Amiruddin dan Asikin, Pengantar Metode Penelitian Hukum (Jakarta: Raja Grafindo Persada, 2004), 119. 
3. Pendekatan kasus (case approach), yaitu terkait dengan adanya praktik dalam bernegara, diantaranya putusan pengadilan baik di bawah Mahkamah Agung dan Mahkamah Konstitusi yang terkait dengan PK. Diantaranya ialah: Putusan Mahkamah Agung No. 1122K/Pid/2015 juncto Putusan PT Bandung No. 120/Pid/2015 juncto Putusan PN Bandung 1530/Pid.B/2014/PN.Bdg, Putusan Mahkamah Agung No. 35/PK/TUN/2009, Putusan Mahkamah Konstitusi No. 34/PUU-XI/2013 dan No. 108/PUU-XIV/2016.

\section{Pengaturan dan Mekanisme Peninjauan Kembali}

Sebelum memberikan telaah terhadap tiga poin yang menjadi rumusan masalah di atas, perlu kiranya dijelaskan terlebih dahulu definisi dan ruang lingkup peninjaun kembali.

Peninjauan Kembali (PK) merupakan salah satu intrumen upaya hukum untuk memperjuangakan hak-hak seseorang yang di atur dalam hukum acara perdata. Sebenarnya peristilahan upaya hukum tidak hanya ditemukan dalam rumpun perdata, upaya hukum juga dapat ditemukan dalam hukum pidana maupun hukum administrasi negara. ${ }^{9}$

Pada dasarnya upaya hukum adalah langkah hukum yang ditempuh subyek hukum atau pihak-pihak untuk menyatakan keberatan atas suatu perkara, baik itu perkara yang masih berlangsung maupun telah diputuskan pengadilan. ${ }^{10}$ Sedangkan secara definitif upaya hukum dapat dimaknai sebagai upaya yang telah disediakan oleh peraturan perundang-undangan untuk perorangan atau badan hukum dalam kaitanya melawan putusan hakim. ${ }^{11}$ Mukti Arto mendefiniskan upaya hukum sebagai media bagi seseorang ataupun badan hukum yang merasa dirugikan

9 Meutia, "Pembatasan Peninjauan Kembali Perkara Perdata Kajian Putusan Mahkamah Konstitusi Nomor 108/PUU-XIV/2016," 226.

10 Meutia, 227.

11 Retno Wulan Sutantio dan Iskandar Oeripkartawinata, Hukum Acara Perdata dalam Teori dan Praktek (Bandung: Mandar Maju, 1997), 142. 
haknya untuk memperolah keadilan dan kepastian hukum melalui cara yang ditentukan oleh undang-undang. ${ }^{12}$

Pada dasarnya tujuan PK adalah demi memenuhi rasa keadilan bagi pencari keadilan karena terdapat kemungkinan dibuka kembali perkara yang sudah diputus oleh pengadilan dan putusan yang telah memperoleh kekuatan hukum tetap. ${ }^{13}$

Secara umum upaya hukum akan diajukan oleh salah satu pihak yang kalah dalam berperkara yang mana hasil putusan dari pengadilan tidak mencerminkan rasa keadilan. Pada umumnya upaya hukum akan diajukan kepada pengadilan yang lebih tinggi. ${ }^{14}$

Dalam ranah kajian hukum perdata, upaya hukum dibedakan menjadi dua jenis. Pertama, upaya hukum biasa yang terdiri dari verzet, banding dan kasasi. Kedua, upaya hukum luar biasa yang terdiri dari peninjuan kembali dan perlawanan terhadap sita eksekutorial. ${ }^{15}$

Secara prinsipil Sudikno Mertokusumo membedakan subtansi antara upaya hukum biasa dan upaya hukum luar biasa. Menurutnya upaya hukum biasa merupakan upaya hukum yang berlaku untuk setiap putusan pengadilan di bawah Mahkamah Agung dengan adanya pembatasan waktu. Sifat dari upaya hukum biasa ialah menghentikan pelaksanaan putusan sementara. Sedangkan upaya hukum luar biasa ialah upaya hukum yang dilakukan oleh seseorang ataupun badan hukum manakala sudah ada putusan pengadilan yang bersifat tetap, namun dikemudian hari terdapat adanya unsur merugikan yang dibuktikan melalui persidangan. ${ }^{16}$

12 Mukti Arto, Praktek Perkara Perdata pada Pengadilan Agama (Yogyakarta: Pustaka Pelajar, 1996), 279.

13 Herri Swantoro, Efa Laela Fakhriah, dan Isis Ikhwansyah, "Permohonan Upaya Hukum Peninjauan Kembali Kedua Kali Berbasis Keadilan dan Kepastian Hukum," Mimbar Hukum 29, no. 2 (2017): 190.

14 V. Harlen Sinaga, Hukum Acara Perdata dengan Pemahaman Hukum Materiil (Jakarta: Erlangga, 2015), 266.

15 Sutantio dan Oeripkartawinata, Hukum Acara Perdata dalam Teori dan Praktek, 142.

16 Sudikno Mertokusumo, Hukum Acara Perdata Indonesia (Yogyakarta: Liberty, 2009), 19. 
Keberadaan upaya hukum berupa peninjauan kembali telah diatur dalam Pasal 67 UU No. 14 Tahun 1985 sebagaimana diubah dengan UU No. 5 Tahun 2004 tentang Mahkamah Agung. Dikatakan dalam Pasal tersebut, bahwa peninjauan kembali dapat dilakukan manakala putusan pengadilan telah mempunyai kekuatan hukum tetap.

Implementasi dari pasal tersebut dapat kita lihat melalui yurisprudendi Mahkamah Agung dalam putusan No. 432K/Sip/1969 yang pada poinya mengatakan bahwa permohonan peninjauan kembali terhadap putusan pengadilan dapat dilakukan apabila putusan telah mempunyai kekuatan hukum tetap dan mengikat.

Putusan yang telah memiliki kekuatan hukum tetap. Tentu tidak akan dipandang secara subjektif oleh hakim maupun pihak lain yang berperkara, namun harus didasarkan pada kondisi tertentu. Yahya Harahap mengatakan bahwa putusan pengadilan yang dapat di ajukan permohonan PK hanyalah putusan yang bersifat kontentiosa. ${ }^{17}$ Demikian juga ditegaskan kembali melalui putusan Mahkamah Agung No. 373K/Pdt/1986 yang pada poinya mengatakan bahwa berdasarkan UU No. 14 Tahun 1985 tentang Mahkamah Agung, dalam ketentuan Pasal 66, 67, dan 68 dikatakan bahwa putusan yang dapat dimintakan PK adalah perkara kontentiosa yang di dalamnya terdapat pihak-pihak yang berperkara (inter-partes).

Kemudian dalam Pasal 66 ayat (1) dikatakan bahwa upaya hukum berupa peninjauan kembali juga dibatasi hanya satu kali. ${ }^{18}$ Pembatasan ini bertujuan untuk menciptakan tertib hukum serta kepastian hukum (legal certainty). ${ }^{19}$

17 M. Yahya Harahap, Kekuasaan Mahkamah Agung Pemeriksaan Kasasi dan Peninjauan Kembali Perkara Perdata (Jakarta: Sinar Grafika, 2008), 443.

${ }^{18}$ Lihat UU No. 14 Tahun 1985 sebagaimana diubah dengan UU No. 5 Tahun 2004 tentang Mahkamah Agung

${ }_{19}$ Bernard Arief Sidharta yang merujuk pada pemikiran Scheltema, bahwa salah satu unsur-unsur negara hukum adalah asas kepastian hukum, yang terdiri dari: a] Asas legalitas, kontitusionalitas dan supremasi hukum; b) Asas non retroaktif; c] Asas peradilan bebas; d) Asas non liquet (hakim tidak boleh menolak perkara); e] Asas pemerintahan berdasarkan atsa hukum dan f) Adanya 
Namun dalam tataran implementasi ternyata PK kedua tidak hanya dalam kasus perdata, melainkan juga terdapat praktik PK ke-dua dalam perkara pidana. ${ }^{20}$ Padahal secara teoritis ataupun ketentuan normatif dalam peraturan perundang-undangan PK dalam perkara perdata hanya dapat dilakukan sebanyak satu kali. Faktanya pernah terbit dua putusan PK dengan objek yang sama namun putusanya berbeda. Mulanya permohonan PK penggugat yang telah dikabulkan oleh majelis, kemudian dimohonkan kembali oleh tergugat dan dikabulkan dengan putusan berbeda oleh mejelis yang berbeda pula. ${ }^{21}$

Padahal PK seharusnya menjadi upaya hukum terakhir yang putusanya bersifat pertama dan terakhir. Hal ini sesuai prinsip dalam persidangan, yang mangatakan bahwa setiap perkara harus ada akhirnya guna menciptakan kepastian hukum (lites finiri oported).

Selain itu jika adanya upaya hukum setelah adanya putusan PK, maka tidak akan ada penyelesaian atas suatu perkara dan cenderung berkepanjangan. Willai e Gladstone pernah mengatakan bahwa "Lustice delayed is justice denied", manaka hukum tertunda, secara tidak langsung hukum tersebut telah mati. ${ }^{22}$

Berikutnya ialah terkait dengan alasan-alasan seseorang atau badan hukum dapat mengajukan upaya hukum PK. Ketentuan Pasal 37 UU tentang Mahkamah Agung telah memberikan limitasi persyaratan seseorang dapat mengajukan upaya hukum PK.

Pertama, PK dapat diajukan manakala suatu putusan didasarkan pada suatu kebohongan atau tipu muslihat pihak lawan. Yahya Harahap memberikan tafsir atas ketentuan

rumusan hak asasi manusia dalam kontitusi. Lihat: B. Arief Sidharta, "Kajian Kefilsafatan tentang Negara Hukum," Jurnal Jentera 2, no. 3 (2004): 121.

20 Ghansam dan Fiska Silvia Raden Roro, "Problematika Peninjauan Kembali Perkara Perdata dalam Tata Hukum Acara Perdata di Indonesia," Jurnal Hukum Acara Perdata Adhaper 1, no. 1 (Juni 2015): 5.

21 Harahap, Kekuasaan Mahkamah Agung Pemeriksaan Kasasi dan Peninjauan Kembali Perkara Perdata, 446.

${ }_{22}$ Tania Sourdin dan Naorm Burstyner, Justice Delayed is Justice Denied (Monash: Monash University, 2013), 1. 
pasal tersebut. Beliau mengatakan, bahwa setidaknya terdapat dua kreteria yang ada dalam pasal 67 tersebut, yakni: putusan didasarkan oleh suatu kebohongan atau tipu muslihat pihak lawan, dan baru diketahui setelah perkara diputus serta putusan disertai bukti-bukti yang kemudian oleh hakim dinyatakan palsu.

Kedua, ditemukanya bukti baru atau novum. Dalam pengajuan upaya hukum PK, keberadaan novum menjadi sangat penting. Setidaknya terdapat beberapa ketentuan terkait dengan novum. (1). Penerapan alasan ini terbatas kepada alat bukti surat, (2). Surat yang digunakan sebagai alat bukti harus bersifat menentukan, (3). Hari dan tanggal alat bukti ditemukan, harus dibawah sumpah pejabat yang berwenang, (4). Alat bukti tersebut ada sebelum proses pemeriksaan perkara.

Ketiga, putusan mengabulkan suatu hal yang tidak dituntut (ultra vires) atau lebih dari pada yang dituntut (ultra petita). ${ }^{23}$

Keempat, terdapat suatu bagian dari tuntutan yang belum diputus tanpa adanya pertimbangan oleh majelis. ${ }^{24}$ Standar ini muncul dari ketentuan Pasal 50 Rv, Pasal 178 ayat (2) HIR dan Pasal 189 RBg, yang memerintahkan hakim wajib mengadili atau memutus tentang keseluruhan bagian. Sehingga ketika perkara diiputus atau diadili tanpa menghitungkan provisi, sita atau permintaan putusan terhadapnya tanpa mempertimbangkan sebab-sebabnya maka putusan yang demikian dapat dimintakan upaya hukum PK.

Kelima, terdapat putusan yang saling bertentangan satu dengan yang lain. ${ }^{25}$ Terpenuhinya syarat ini, manakala telah sesuai dengan unsur-unsur sebagai berikut:

23 Lihat ketentuan Pasal 67 huruf c UU No. 14 Tahun 1985 tentang Mahkamah Agung

24 Lihat ketentuan Pasal 67 huruf d UU No. 14 Tahun 1985 tentang Mahkamah Agung

25 Lihat ketentuan Pasal 67 huruf e UU No. 14 Tahun 1985 tentang Mahkamah Agung 
1. Terdapat dua atau lebih putusan yang saling bertentangan.

2. Pihak yang terlibat dalam putusan tersebut sama.

3. Soal dan dasar yang digunakan sama.

4. Diperiksa oleh pengadilan yang sama.

Keenam, terdapat suatu kekhilafan oleh hakim atau kekeliruan yang nyata. Alasan-alasan di atas merupakan alasan yang wajib ada, manakala seseorang atau badan hukum akan mengajukan upaya hukum PK. Normalnya PK harus diajukan sebanyak satu kali, dengan diputusnya oleh mejelis yang mengadili upaya hukum PK, maka perkara telah dinyatakan selesai.

Terdapat beberapa instrumen hukum, baik UU ataupun Surat Edaran Mahkamah Agung (SEMA) yang menyatakan bahwa PK hanya adapat dilakukan sebanyak satu kali. Pertama, Pasal 66 ayat (1) UU. No. 3 Tahun 2009 sebagaimana perubahan ketiga UU No. 18 Tahun 1985 tentang Mahkamah Agung. Dalam ketentuan pasal tersebut dikatakan bahwa upaya hukum PK dapat diajukan hanya satu kali. Kemudian kia juga bisa menemui dalam SEMA No. 10 Tahun 2009, SEMA yang dikeluarkan tanggal 12 Juni 2009 ini bentuk penegakan atas prinisp kepastian hukum. SEMA ini ditujukan kepada seluruh peradilan di bawah Mahkamah Agung untuk hanya menerima permohonan PK sebanyak satu kali. Berikutnya kita juga dapat menemukan dalam SEMA No. 7 Tahun 2014. SEMA ini merupakan respon dari adanya Putusan Mahkamah Konstitusi No. 34/PUUXI/2013, yang mana pada poinya Mahkamah Konstitusi memperbolehkan PK lebih dari satu kali untuk perkara pidana.

\section{Ratio Decidendi Putusan Mahkamah Konstitusi No. 34/PUU-XI/2013 dan No. 108/PUU-XIV/2016}

Sebelum memberikan telaah terhadap ratio decidenci putusan Mahkamah Konstitusi, perlu kiranya diketahui alasan-alasan pemohon dalam mengajukan gugatan constitutional review. 
Putusan No. 34/PUU-XI/2013 ini merupakan gugatan yang diajukan oleh pemohon Antasari Azhar untuk menguji konstitusionalitas Pasal 268 ayat (3) UU No. 8 Tahun 1981 tentang Hukum Acara Pidana. Dalam permohonanya pemohon beranggapan bahwa Pasal 268 KUHAP telah bertentangan dengan Pasal 1 ayat (3), Pasal 24 ayat (1), Pasal 28 C ayat (1), dan Pasal 28 D ayat (1) UUD 1945.

Alasan-alasan yang digunakan oleh pemohon diantaranya:

1. Bahwa hak untuk mendapatkan keadilan adalah hak setiap warga negara tanpa terkecuali terutama warga negara yang sedang memperjuangkan keadilan dan siapapun tidak boleh menghalangi.

2. Bahwa kepastian hukum harus diletakkan dalam rangka penegakan hukum yang berkeadilan (justice inforcement), sehingga manakala diantara keduanya tidak sejalan maka keadilanlah yang seharusnya didahulukan. Sebab hukum adalah alat untuk menegakkan keadilan materiil serta substansial di masyarakat, bukan hanya menegakkan keadilan formalitas.

3. Bahwa persamaan di depan hukum (equality before the law) dan nilai-nilai keadilan telah tereduksi oleh ketentuan yang membatasi peninjauan kembali lebih dari satu kali sebagaimana diatur dalam ketentuan UU yang dimohonkan oleh pemohon untuk di uji.

Atas alasan-alasan tersebut, pemohon meminta kepada Mahkamah Konstitusi untuk menyatakan Pasal 268 ayat (3) KUHAP yang menyatakan bahwa PK hanya dapat diajukan sebanyak satu kali, bertentangan dengan UU 1945.

Dalam praktik hukum tidak jarang kita menemui berbenturanya asas kepastian hukum dan keadilan. Kepastian hukum yang bermuara pada aspek prosedural sangat penting untuk memberikan jaminan penegakan hukum. Disisi lain aspek keadilan sangat penting karena bermuara kepada kepentingan umum. Nilai keadilan dan kebenaran tidak dapat diperoleh dari tingginya aspek 
kapastian hukum, melainkan akan ditentukan dari faktor keseimbangan.

Berdasar hal tersebut, Mahkamah Konstitusi menempatkan dirinya sebagai the guardian of human rights telah memilih aspek keadilan dari pada aspek kepastian hukum. Hal tersebut tercermin dalam Putusan No. No. 34/PUU-XI/2013 tentang pengujian UU No. 8 Tahun 1981 tentang Hukum Acara Pidana, yang mana pada amar putusanya Mahkamah Konstitusi menyatakan Pasal 268 ayat (3) KUHAP telah bertentangan dengan UUD 1945 dan tidak memiliki kekuatan hukum mengikat.

Mahkamah Konstitusi dalam pokok pertimbanganya mengatakan:

"Bahwa upaya hukum luar biasa (PK) secara historis filosofis merupakan hukum yang lahir demi melindungi terpidana. MK berpendapat upaya hukum PK berbeda dengan banding ataupun kasasi sebagai upaya hukum biasa. Upaya hukum biasa harus dikaitkan dengan prinsip kepastian hukum karena tanpa kepastian hukum, yaitu dengan menentukan limitasi waktu dalam pengajuan upaya hukum biasa, justru akan menimbulkan kepastian hukum yang tentu akan melahirkan ketidakadilan dan proses hukum yang tidak sesuai. Dengan demikian, ketentuan yang menjadi syarat dapat ditempuhnya upaya hukum biasa disamping terkait dengan kebenaran materiil yang hendak dicapai, juga terkait persyaratan formil yaitu terkait dengan tenggang waktu tertentu setelah diketahuinya suatu putusan hakim oleh para pihak secara formal. Adapun upaya hukum biasa bertujuan untuk menemukan keadilan dan kebenaran materiil. Keadilan tidak dapat dibatasi oleh waktu atau ketentuan formalitas yang membatasi bahwa upaya hukum luar biasa (PK) hanya dapat diajukan satu kali. Karena mungkin saja setelah diajukan PK dan diputus ada keadaan baru (novum) yang substansial baru ditemukan, yang pada saat PK sebelumnya belum ditemukan". 
Putusan Mahkamah Konstitusi tersebut mempersyaratkan seseorang yang akan mengajukan PK harus memenuhi kriteria sebagaimana diatur dalam Pasal 263 ayat (2) KUHAP, artinya Putusan tersebut merupakan consitionally constitutional selama dimaknai terpenuhinya ketentuan sebagaimana yang dipersyaratkan dalam Pasal 263 ayat (2). Persyaratan yang dimaksud ialah sebagai berikut:

1. Terdapat dugaan baru yang menimbulkan dugaan kuat, bahwa jika keadaan tersebut sudah diketahui pada saat persidangan masih berlangsung, hasilnya berupa putsan bebas atau lepas dari segala tuntutan hukum.

2. Apabila dalam berbagai putusan terdapat pernyataan bahwa sesuatu dapat terbukti, akan tetapi hal atau keadaan yang digunakan sebagai dasar tersebut telah bertentangan dengan suatu yang lain.

3. Apabila putusan tersebut dengan jelas merupakan kekhilafan hakum.

Terlihat jelas bahwa putusan Mahkamah Konstitusi tersebut sesuai dengan nilai-nilai keadilan yang berkembang di masyarakat. Pemilihan keadilan dari pada kepastian hukum dalam mencapai keadilan subtantif sangatlah diperlukan. Hal ini sejalan dengan pernyataan Gustav Readbruch yang mengatakan bahwa "Apabila hakim harus memilih antara keadilan dan kebermanfaatan maka pilihlah keadilan, apabila hakum harus memilih antara kebermanfaatan dan kepastian hukum maka pilihlah kebermanfaatan. ${ }^{26}$

Tentu berbeda dengan Putusan MK No. 108/PUUXIV/2016 tentang pengujian Pasal 66 ayat (1) UU No. UU No. 3 Tahun 2009 sebagaimana perubahan kedua atas UU No. 18 Tahun 1985 tentang Mahkamah Agung dan Pasal 24 ayat (2) UU Kekuasaan Kehakiman.

Mahkamah berpendapat bahwa pembatasan PK bagi perkara selain pidana tetap harus dibatasi. Mahkamah juga

26 Mubarok, "Penemuan Hukum sebagai Pertimbangan Sosiologis Hakim Agama dalam Menerapkan Hukum," 371. 
mendasarkan pada putusan sebelumnya No. 16/PUUVIII/2010 yang dalam pertimbangan hukumnya mengatakan sebagai berikut:

“...jika ketentuan permohonan peninjauan kembali sebagai upaya hukum luar biasa tidak dibatasi maka akan terjadi ketidakjelasan dan kepastian hukum sampai beberapa kali upaya hukum dilakukan"

"Keadaan demikian akan menimbulkan ketidakpastian hukum yang adil kapan suatu perkara akan berakhir yang justru bertentangan dengan ketentuan UUD 1945 yang harus memberikan pengakuan, jaminan, perlindungan, dan kepastian hukum yang adil terhadap setiap orang. Benar bahwa hak setiap orang untuk mencari dan mendapat keadilan di jamin oleh konstitusi. Hak tersebut tidaklah bersifat mutlak melainkan dapat dibatasi menurut ketentuan Pasal 28J ayat (2) UUD 1945 yang menentukan bahwa dalam menjalankan hak dan kebebasanya, setiap orang wajib tunduk kepada pembatasan yang ditetapkan dalam Undang-Undang dengan masksud semata-mata untuk menjamin pengakuan serta penghormatan atas hak dan kebebasan orang lain dan untuk memenuhi tuntutan yang adil sesuai dengan pertimbangan moral, nilai-nilai agama, keamanan, dan ketertiban umum dalam masyarakat demokratis".

"Mahkamah Konstitusi berpendapat bahwa pembatasan yang ditentukan dalam pasal UndangUndang a quo tidak bersifat diskriminatif sebagaimana dimaksud dalam Pasal 28I ayat (2) UUD 1945, karena pembatasan tersebut berlaku secara objektif kepada semua warga negara dalam penegakan hukum di Pengadilan. Pembatasan ini bermaksud untuk memberikan kepastian hukum atas penyelesaian perkara, sehingga seseorang tidak dengan mudahnya melakukan upaya hukum peninjauan kembali secara berulang-ulang. Lagi pula pembatasan ini sejalan dengan proses peradilan yang menhendaki diterapkanya asas sederhana, cepat, dan biaya ringan. 
Dengan pembatasan itu pula akan terhindarkan adanya proses peradilan yang berlarut-larut yang mengakibatkan berlarut-larutnya upaya memperoleh keadilan yang pada akhirnya justru dapat menimbulkan pengingkaran terhadap keadilan itu sendiri sebagaimana digambarkan dalam adagium "justice delayed justice denied".

Terlihat pembedaan yang sangat jelas dari pertimbangan Mahkamah Konstitusi melalui putusan No. 34/PUU-XI/2013 dan No. 108/PUU-XIV/2016. Putusan No. 34/PUU-IX/2013 tentang pengujian Pasal 268 ayat (3) UU No. 8 Tahun 1981 tentang Hukum Acara Pidana dinyatakan inskonstitusional, artinya pasal tersebut tidak lagi mempunyai kekuatan hukum mengingkat. Kemudian putusan No. 108/PUU-XIV/2016 tentang pengujian Pasal 66 ayat (1) UU No. UU No. 3 Tahun 2009 sebagaimana perubahan kedua atas UU No. 18 Tahun 1985 tentang Mahkamah Agung dan Pasal 24 ayat (2) UU Kekuasaan Kehakiman dinyatakan konstitusional, artinya tidak ada pertentangan antara pasal tersebut dengan pasal-pasal dalam UUD 1945.

\section{Pembedaan Perlindungan HAM Bagi Warga Negara dalam Kasus Pidana dan Perdata}

Sebelum menelaah terkait dengan pembedaan penempatan konstitusionalitas bagi setiap warga negara, baik dalam perkara pidana ataupun perdata, perlu kiranya didudukan kembali hakikat dibentuknya Mahkamah Konstitusi di Indonesia, yang merupakan lembaga yang berfungsi melaksanakan kekuasaan kehakiman di samping Mahkamah Agung (MA). ${ }^{27}$

Gagasan pembentukan Mahkamah Konstitusi berawal dari kebutuhan untuk terselenggaranya gagasan pengujian konstitusional (constitutional review) yang kemudian disebut dengan judicial review. MK hadir sebagai bagian dari

27 Muwahid, "Sistem Ketatanegaraan Indonesia Pasca Amandemen UUD $1945, " 385$. 
upaya mewujudkan mekanisme checks and balances antar cabang kekuasaan negara berdasarkan sistem demokrasi.

Keberadaan Mahkamah Konstitusi dapatlah dikatakan sebagai sesuatu yang cukup fenomenal dalam konstelasi ketatanegaraan di Indonesia. Disamping keberadaanya yang masih baru, Mahkamah Konstitusi memiliki kewenangan yang cukup spesifik, yakni hanya menangani kasus-kasus ketatanegaraan.

Berdasarkan ketentuan Pasal 24C ayat (1) UUD NRI 1945 pasca amandemen, Mahkamah Konstitusi setidaknya memiliki empat kewenangan dan satu kewajiban. Kewenangan tersebut diantaranya ialah:

1. Mengadili pada tingkat pertama dan terakhir yang putusanya bersifat final dan mengikat untuk menguji undang-undang terhadap Undang-undang Dasar.

2. Mengadili sengketa antar lembaga negara yang kewenanganya diberikan oleh undang-undang.

3. Memutus pembubaran partai politik.

4. Memeriksa dan memutus perselisihan hasil pemilu.

Adapun kewajiban Mahkamah Konstitusi ialah memberikan putusan atas pendapat Dewan Perwakilan Rakyat (DPR) terkait dugaan presiden dan wakil presiden telah melakukan pelanggaran menurut UUD NRI 1945. ${ }^{28}$ Selain itu, sejak keluarnya UU No. 12 Tahun 2008 Mahkamah Konstitusi diberikan kewenangan baru, yakni memeriksa dan memutus perselisihan hasil kepala daerah. ${ }^{29}$

Maka dari itu, dapat dikatakan bahwa gagasan pembentukan Mahkamah Konstitusi adalah upaya untuk menegakkan prinsip-prinsip negara hukum dan memberikan perlindungan secara maksimum terhadap demokrasi dan hak-hak dasar warga negara. Perlindungan hak-hak dasar ini menjadi penting untuk digaris bawahi oleh setiap negara yang menganut doktrin pemahaman negara hukum, yang mana menempatkan konstitusi sebagai hukum tertinggi (the supreme of the land) dalam sebuah negara yang

${ }^{28}$ Muwahid, 398.

29 Moh Mahfud MD, Konstitusi dan Hukum dalam Kontroversi Isu (Jakarta: Raja Grafindo Persada, 2012), 262. 
bersangkutan. Karena tatkala hak-hak dasar tersebut dimasukkan dalam konstitusi, secara logis hak-hak tersebut menjadi bagian yang tidak terpisahkan oleh konstitusi itu sendiri serta mengikat kepada setiap kekuasaan negara. ${ }^{30}$

Sebagaimana telah diketahui Mahkamah Konstitusi telah memberikan juran dikotomi yang dalam dalam pemberian hak asasi manusia bagi warga negara. Jurang tersebut bermula dari pembedaan jumlah upaya hukum PK. Dalam kasus pidana Mahkamah berpendapat keadilan yang dicari ialah keadilan subtantif, sehingga manakala terdapat pembatasan upaya hukum PK keadilan tersebut tidak akan tercapai. Sedangkan dalam kasus perdata Mahkamah berpendapat bahwa hanya keadilan formil yang dicari, sehingga dalam hal ini mahkamah lebih mengutamakan aspek kepastian hukum.

Padahal jikalau menelaah dari kedua pertimbangan hukum Mahkamah Konstitusi pada Putusan No. 34/PUUXI/2013 dan No. 108/PUU-XIV/2016 tidak ada pemdaan yang signifikan. Dalam pengujian Pasal 66 ayat (1) UU No. UU No. 3 Tahun 2009 sebagaimana perubahan kedua atas UU No. 18 Tahun 1985 tentang Mahkamah Agung dan Pasal 24 ayat (2) UU Kekuasaan Kehakiman, setidaknya terdapat dua pendapat Mahkamah yang utama, yakni perlunya kepastian hukum dalam sebuah putusan serta menerapkan asas litis finiri operated (Setiap perkara harus ada akhirnya).

Pada umumnya dalam setiap praktik penegakan hukum terdapat prinsip yang harus dijadikan pedoman. Prinsip tersebut ialah due process of law (setiap orang harus ditempatkan yang sama di depan hukum). Prinsip ini tidak terbatas dalam kasus pidana ataupun perdata saja, melainkan setiap perkara yang diajukan dalam peradilan wajib bagi hakim hukumnya untuk menerima, memeriksa, dan mengadili. ${ }^{31}$

30 Durga Das Basu, Human Rights in Constitutional Law (New Delhi-NagpurArgra: Wadhama and Company, 2003), 48-78.

31 Mardjono Reksodiputro, Bunga Rampai Permasalahan Dalam Sistem Peradilan: Kumpulan Karangan Buku ke-Lima (Jakarta: Pusat Pelayanan dan Pengabdian Hukum Lembaga Kriminologi Universitas Indonesia, 2007), 8. 
Sehingga dalam hal ini, pembatasan ataupun pengingkaran terhadap asas litis finiri operated harus dimaknai dalam suatu batasan-batasan tertentu guna memperoleh keadilan serta memberikan kedudukan setiap orang sama di depan hukum.

Pembatasan-pembatasan tersebut sebanarnya sudah diatur pula dalam peraturan perundang-undangan, misalnya dalam hal ini adanya persyaratan bahwa setiap orang atau badan hukum yang hendak mengajukan upaya hukum luar bisas (PK) harus menemukan bukti baru (novum).

Selain itu, upaya hukum PK merupakan upaya hukum yang dapat diajukan setelah putusan pengadilan mempunyai kekuatan hukum tetap. Artinya, sebenarnya tidak ada pengingkaran juga jikalau dipandang secara prosedural. Karena setiap putusan yang telah memperoleh kekuatan hukum tetap dapat dilaksanakan sebuah eksekusi.

Padahal hak asasi manusia sebagaimana yang diberikan oleh konstitusi kepada setiap warga negaranya tidak bisa dipandang dari sudut pandang pidana saja. Terlebih keberadaan hak-hak yang tidak bisa dibatasi dalam keadaan apapun (non derogable rights), sebagaimana dituangkan dalam Pasal 28I UUD 1945.

Kita juga tidak boleh luput meskipun hakim merupakan manifestasi pembawa keadilan di dunia, hakim juga seorang manusia biasa yang tidak luput akan kekeliruan dan kesalahan, oleh sebab itu, sarana untuk melakukan koreksi terhadap suatu putusan harus terbuka selebarlebarnya guna memberikan jaminan keadilan terhadap setiap warga negara.

Manakala negara melalui intrumen hukumnya, telah menutup kran upaya hukum PK hanya satu kali. Pertanyaan yang mendasar, bagaimana kemudian jika dalam suatu putusan ternyata memang benar-benar ditemukan alat bukti baru (novum) yang berdasarkan potensial nyata dapat memengaruhi hasil putusan? Bagaimana pula jikalau dalam putusan telah ditemukan kekhilafan hakim dalam memberikan pertimbangan hukum yang jelas seharusnya tidak demikian? Pertanyaan-pertanyaan tersebut tentu 
tidak bisa diselesaikan manakala upaya hukum hanya terbatas satu kali.

Dalam perkara perdata, setidaknya terdapat dua pasal dalam UUD 1945 yang tidak boleh kita lupakan. Pertama, Pasal 28G ayat (1) yang berbunyi "Setiap orang berhak atas perlindungan diri pribadi, keluarga, kehormatan, martabat, dan harta benda yang di bawah kekuasanya, serta berhak atas rasa aman dan perlindungan dari ancaman ketakutan untuk berbuat atau tidak berbuat sesuatu yang merupakan hak asasi".

Ketentuan pasal tersebut mengandung makna, bahwa negara berkewajiban untuk tidak hanya melindungi jiwa setiap warga negara dari serangan pihak lain, tetapi juga berkewajiban untuk melindungi harta setiap warga negara khususnya dari perbuatan melawan hukum ataupun upaya kejahatan yang dilegitimasi oleh hukum.

Kedua, Pasal $28 \mathrm{H}$ ayat (4) yang mengatakan bahwa "Setiap orang berhak mempunyai hak milik pribadi dan hak milik tersebut tidak boleh diambil alih secara sewenangwenang oleh siapapun".

Penggunaan frasa "setiap orang", dalam pasal tersebut mengandung makna bahwa tidak hanya diposisikan dalam kasus tertentu seseorang dapat diberikan perlindungan hukum yang sama. Misalnya, dalam kasus pencurian yang mengikuti rumpun hukum pidana. Kemudian dapat diajukan upaya hukum PK, namun sudah menjadi kewajiban pula dalam perkara perdata misalnya sengketa tanah.

Oleh sebab itu, pembedaan pemberian keadilan dalam semangat menjaga jiwa konstitusi melalui pembatasan upaya hukum PK dalam perkara perdata dan pidana sudah melenceng dari niatan konstitusi untuk melindungi seluruh warga negaranya. Pembatasan jumlah upaya hukum PK dengan membenturkan prinsip kepastian hukum serta asas litis finiri operated tidak dapat dibuktikan karena kedua asas tersebut telah termanifestasikan melalui persyaratan-persyaratan PK. Sehingga dalam hal ini pemenuhan prinsip due process of law bagi seluruh warga 
negara, termasuk upaya hukum PK ke dua dalam perkara perdata menjadi sebuah kewajiban untuk menjaga prinsipprinsip keadilan yang terkandung di dalam konstitusi.

\section{Penutup}

Berdasarkan pemaparan di atas setidaknya terdapat beberapa poin yang dapat disimpulkan. Pertama, Mahkamah Konstitusi sebagai the guardian of human rights telah memberikan pengklasifikasian yang berbeda dalam hal upaya hukum peninjauan kembali. Mahkamah dalam putusanya No. 34/PUU-XI/2013 tentang pengujian Pasal 268 ayat (3) UU No. 8 Tahun 1981 tentang Hukum Acara Pidana dinyatakan inskonstitusional, artinya pasal a quo telah bertentangan dengan konstitusi dan tidak lagi mempunyai kekuatan hukum mengingkat. Kemudian dalam putusan No. 108/PUU-XIV/2016 tentang pengujian Pasal 66 ayat (1) UU No. UU No. 3 Tahun 2009 sebagaimana perubahan kedua atas UU No. 18 Tahun 1985 tentang Mahkamah Agung dan Pasal 24 ayat (2) UU Kekuasaan Kehakiman, Mahkamah menyatakan pasal a quo konstitusional. Artinya pasal-pasal tersebut tetap dapat digunakan oleh seseorang manakala akan melakukan upaya hukum peninjauan kembali.

Kedua, Putusan Mahkamah No. 34/PUU-XI/2013 tentang Hukum Acara Pidana lebih menekankan pada aspek keadilan meteriil dan seolah menegasikan prinsip kepastian hukum. Sedangkan putusan Mahkamah No. 108/PUUXIV/2016 tentang pengujian Pasal 66 ayat (1) UU No. UU No. 3 Tahun 2009 sebagaimana perubahan kedua atas UU No. 14 Tahun 1985 tentang Mahkamah Agung dan Pasal 24 ayat (2) UU Kekuasaan Kehakiman lebih condong terhadap pentingnya aspek kepastian hukum dan menerapkan asas litis finiri operated (Setiap perkara harus ada akhirnya).

\section{Daftar Pustaka}

Amiruddin, dan Asikin. Pengantar Metode Penelitian Hukum. Jakarta: Raja Grafindo Persada, 2004. 
Arto, Mukti. Praktek Perkara Perdata pada Pengadilan Agama. Yogyakarta: Pustaka Pelajar, 1996.

Basu, Durga Das. Human Rights in Constitutional Law. New DelhiNagpur-Argra: Wadhama and Company, 2003.

Ghansam, dan Fiska Silvia Raden Roro. "Problematika Peninjauan

Kembali Perkara Perdata dalam Tata Hukum Acara Perdata di Indonesia." Jurnal Hukum Acara Perdata Adhaper 1, no. 1 (Juni 2015).

Harahap, M. Yahya. Kekuasaan Mahkamah Agung Pemeriksaan Kasasi dan Peninjauan Kembali Perkara Perdata. Jakarta: Sinar Grafika, 2008.

Kaelan. Inkonsistensi dan Inkoherensi dalam Undang-undang Dasar Negara Republik Indonesia Tahun 1945 Hasil Amandemen (Kajian Filosofis dan Yuridis). Yogyakarta: Paradigma, 2016.

Mahfud MD, Moh. Konstitusi dan Hukum dalam Kontroversi Isu. Jakarta: Raja Grafindo Persada, 2012.

Mertokusumo, Sudikno. Hukum Acara Perdata Indonesia. Yogyakarta: Liberty, 2009.

Meutia, Pityani. "Pembatasan Peninjauan Kembali Perkara Perdata Kajian Putusan Mahkamah Konstitusi Nomor 108/PUU-XIV/2016." Jurnal Legislasi Indonesia 16, no. 2 (2019).

Mubarok, Nafi'. "Penemuan Hukum sebagai Pertimbangan Sosiologis Hakim Agama dalam Menerapkan Hukum." Jurnal Al-Qānūn 17, no. 2 (Desember 2014).

Muwahid. "Sistem Ketatanegaraan Indonesia Pasca Amandemen UUD 1945." Jurnal Al-Qa>nu>n 13, no. 2 (Desember 2010).

Reksodiputro, Mardjono. Bunga Rampai Permasalahan Dalam Sistem Peradilan: Kumpulan Karangan Buku ke-Lima. Jakarta: Pusat Pelayanan dan Pengabdian Hukum Lembaga Kriminologi Universitas Indonesia, 2007.

Sidharta, B. Arief. "Kajian Kefilsafatan tentang Negara Hukum." Jurnal Jentera 2, no. 3 (2004).

Sinaga, V. Harlen. Hukum Acara Perdata dengan Pemahaman Hukum Materiil. Jakarta: Erlangga, 2015.

Sourdin, Tania, dan Naorm Burstyner. Justice Delayed is Justice Denied. Monash: Monash University, 2013.

Suhariyanto, Budi. “Aspek Hukum Peninjauan Kembali Lebih dari Satu Kali dalam Perkara Pidana (Perspektif Penegakan 
Keadilan, Kepastian dan Kemanfaatan Hukum)." Jurnal Hukum dan Peradilan 4, no. 2 (2015).

Sutantio, Retno Wulan, dan Iskandar Oeripkartawinata. Hukum Acara Perdata dalam Teori dan Praktek. Bandung: Mandar Maju, 1997.

Swantoro, Herri, Efa Laela Fakhriah, dan Isis Ikhwansyah. "Permohonan Upaya Hukum Peninjauan Kembali Kedua Kali Berbasis Keadilan dan Kepastian Hukum." Mimbar Hukum 29, no. 2 (2017).

Triwati, Ani. "Upaya Hukum Peninjauan Kembali Dalam Perkara Pidana Pasca Putusan Mahkamah Konstitusi." Jurnal Dinamika Sosial Budaya 17, no. 2 (2015). 